\title{
Growth of planted jack pine (Pinus banksiana) and natural regeneration ten years after pre- and post-harvest spraying and partial cutting in an Ontario boreal mixedwood forest
}

\author{
by Rongzhou Man ${ }^{1}$ and G. Blake MacDonald²
}

\begin{abstract}
The conventional plantation approach to regenerating jack pine (Pinus banksiana) after harvesting maximizes pine growth but may reduce wood quality. In this study we examined growth of planted jack pine and natural regeneration after herbicide spraying and partial cutting treatments on a boreal mixedwood site in northeastern Ontario. Treatments were pre-harvest aerial spray, post-harvest ground spray in strips (partial spray), partial cut, and post-harvest aerial broadcast spray; an untreated reference stand was used for comparison. Pre-harvest spray was as effective as partial cutting and post-harvest broadcast spray in suppressing trembling aspen regeneration and providing adequate light for survival and growth of planted jack pine. Ten years after planting, mortality and growth of pines in the pre-harvest treatment were comparable to those in the partial and broadcast spray treatments. Due to vigorous growth of broadleaf species [mostly red maple; (Acer rubrum)], and shade from the residual overstory, jack pine was smallest in the partial cut treatment; however, based on branch size, branch-free stem length and stem taper, wood quality was highest in this treatment. Considering factors important to forest managers such as growth and quality of planted jack pine, treatment costs, and proportion of the harvested blocks allocated to conifer production, the preferred treatment was pre-harvest spray.
\end{abstract}

Keywords: pre-harvest spray, herbicide, Pinus banksiana, conifer-broadleaf mixtures, wood quality, mixedwood silviculture

\section{RÉSUMÉ}

Lapproche traditionnelle par la plantation pour régénérer le pin gris (Pinus banksiana) après récolte maximise la croissance du pin, mais pourrait réduire la qualité du bois. Dans cette étude, nous avons évalué la croissance de pins gris naturels et plantés soumis à une pulvérisation d'herbicide et à une coupe partielle sur un parterre de forêt boréale mixte dans le nord-est de l'Ontario. Les traitements consistaient en une pulvérisation aérienne effectuée avant la récolte, une pulvérisation terrestre par bandes après la récolte (pulvérisation partielle), une coupe partielle et une pulvérisation densemble par voie aérienne; un peuplement témoin laissé intact a été utilisé à des fins de comparaison. La pulvérisation effectuée avant la récolte a été aussi efficace que la coupe partielle et la pulvérisation d’ensemble pour supprimer la régénération de peuplier faux-tremble et fournir la luminosité nécessaire pour la survie et la croissance du pin gris en plantation. Dix ans après plantation, la mortalité et la croissance des pins dans les blocs traités avant la récolte étaient comparables à celles des blocs ayant subi une coupe partielle et une pulvérisation d’ensemble. En raison de la croissance vigoureuse des feuilles (principalement lérable rouge; Acer rubrum) et à lombre produite par létage supérieur résiduel, la taille du pin gris était plus faible dans les blocs de coupe partielle; toutefois, en considérant la dimension des branches, la longueur de tronc sans branches et le défilement de la tige, cest ce traitement qui a donné le bois de meilleure qualité. Sur la base de facteurs importants pour les aménagistes comme la croissance et la qualité des pins gris plantés, les coûts des traitements et la proportion des blocs récoltés retournant à la production résineuse, cest la pulvérisation avant récolte qui aura été le meilleur traitement.

Mots clés : pulvérisation avant récolte, herbicide, Pinus banksiana, peuplements mixtes conifères-feuillus, qualité du bois, sylviculture des peuplements mélangés

\footnotetext{
${ }^{1}$ Ontario Ministry of Natural Resources and Forestry, Ontario Forest Research Institute, 1235 Queen Street East, Sault Ste. Marie, Ontario P6A 2E5. Corresponding author. E-mail: rongzhou.man@ontario.ca

${ }^{2} 608$ - 265 Poulin Avenue, Ottawa, Ontario K2B 7Y8 E-mail: macdonaldb@bell.net
} 


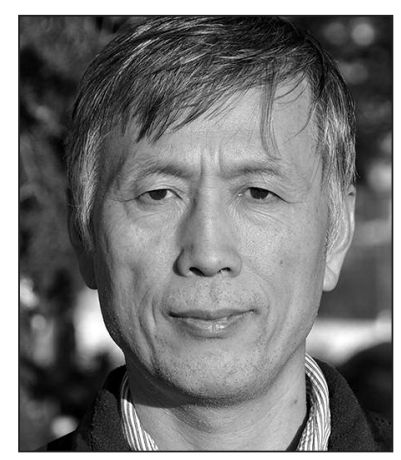

Rongzhou Man

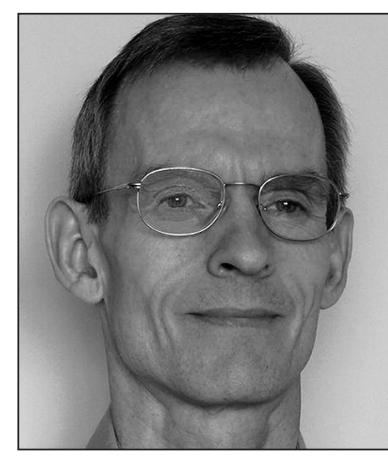

G. Blake MacDonald

\section{Introduction}

Jack pine (Pinus banksiana Lamb.) is widely distributed over a range of site and climatic conditions in North America (Rudolph and Laidly 1990). While it usually forms pure stands on sandy or dry sites, jack pine often grows in mixtures with trembling aspen (Populus tremuloides Michx.), white birch (Betula papyrifera Marsh), white spruce (Picea glauca [Moench] Voss), black spruce (Picea mariana [Mill.] BSP), and balsam fir (Abies balsamea [L.] Mill.) on mesic sites (Rudolph and Laidly 1990, MacDonald 1995). In Ontario, mixedwood stands dominated by jack pine account for over $25 \%$ of the boreal mixedwood forest on an area basis, second only to those dominated by trembling aspen (Towill et al. 2004).

Regenerating jack pine after harvesting of mixedwood stands generally involves site preparation and planting followed by applications of herbicide to control competition (Galloway 1986, Béland et al. 1999). As a shade-intolerant boreal conifer, jack pine is subject to growth loss and mortality under broadleaf, shrub or herbaceous competition (Bell 1991, Bell et al. 2000, Pitt et al. 2000, Bell et al. 2011), but at low stand densities, non-genetically improved stock is often branchy and has poor stem form (Rudolph and Laidly 1990, $\mathrm{Lu}$ et al. 2012). High planting densities result in improved stem form but also increase establishment and subsequent stand density management costs.

Managing jack pine in mixtures with naturally regenerated broadleaves or tolerant conifers of appropriate height and density could assist natural pruning and promote species and structural biodiversity and ecosystem stability without severely reducing pine survival and growth. Partial cutting of the overstory canopy increases the amount of light available to planted seedlings (Man and Lieffers 1999, MacDonald et al. 2004). In the mixedwood forests of eastern Canada, however, the understory often has abundant shade-tolerant shrubs such as mountain maple (Acer spicatum Lam.) and beaked hazel (Corylus cornuta Marsh.) that can substantially reduce survival of planted seedlings (Bell 1991, Pitt et al. 2000). A $50 \%$ canopy removal that allowed sufficient light for reasonable survival of white spruce was inadequate for planted jack pine (Man et al. 2009). Under a partial canopy, post-planting vegetation control is required to increase survival of planted jack pine and even then seedling growth will be reduced relative to what would be expected in a clearcut (Man et al. 2009).

Modified herbicide use that reduces but does not eliminate competitive vegetation may be a more practical approach to growing conifers in mixedwood stands. Herbicide can be used at reduced concentrations or applied to a portion of the area through spot, strip or pulse application (Comeau et al. 2005, Lieffers et al. 2008). The density and growth of aspen suckers can also be controlled by spraying the mature canopy before harvesting to increase subsequent survival and growth of planted conifers (MacDonald et al. 2003; Man et al. 2010, 2011). Ten years after planting, spruce seedlings were nearly $5 \%$ taller after pre-harvest compared with post-harvest spray treatments, although the root collar diameter of the seedlings was $10 \%$ smaller (Man et al. 2013). How jack pine seedlings would respond to pre-harvest spray treatments relative to post-harvest spray or partial cutting treatments has not been documented.

The objective of this study was to compare the effects of pre- and post-harvest herbicide spray and partial cutting on the (1) understory light and vegetation cover, (2) density and growth of natural regeneration, and (3) growth, mortality and quality of planted jack pine 10 years after treatment on a boreal mixedwood site in northeastern Ontario.

\section{Methods}

\section{Site description}

The site conditions, experimental design, and harvesting treatments were described in detail by MacDonald et al. (2003) and Man et al. (2011) and are summarized briefly here. The study site is located in two harvesting blocks southwest of Gogama, Ontario (approximate coordinates of the blocks are $47^{\circ} 30^{\prime} \mathrm{N}, 81^{\circ} 57^{\prime} \mathrm{W}$ and $47^{\circ} 30^{\prime} \mathrm{N}, 82^{\circ} 00^{\prime} \mathrm{W}$ ). Prior to harvesting, the overstory was dominated by 70 -year-old trembling aspen ( $51 \%$ of overstory basal area), with minor components of white birch (13\%), jack pine (12\%), red maple (11\%), black spruce (6\%), white spruce (5\%) and balsam fir (2\%). Understory trees were mainly red maple (5217 stems ha-1), balsam fir (1929 stems ha-1), and trembling aspen (1413 stems ha ${ }^{-1}$ ); shrub species were predominantly mountain maple, beaked hazel and bush honeysuckle (Diervilla lonicera Mill.). The soil is stony to bouldery ablation till and varies from silt to silt loam and silty sand.

\section{Experimental design and treatments}

The original study design followed a randomized complete block with five treatments replicated three times (MacDonald et al. 2003, Man et al. 2011). The treatments were: (1) pre-harvest aerial spraying with glyphosate to suppress trembling aspen regeneration and produce intimate mixtures of conifers and broadleaves (subsequently referred to as pre-harvest spray); (2) post-harvest ground spraying with glyphosate to produce alternating 10-m-wide sprayed and unsprayed strips favouring conifers and broadleaves, respectively (partial spray); (3) partial cutting with no spraying to produce alternating $10-\mathrm{m}$-wide harvested and leave corridors to suppress shade-intolerant vegetation and favour the growth of conifers (partial cut); (4) post-harvest aerial spraying with glyphosate to produce conventional conifer plantations (broadcast spray); and, (5) an untreated reference stand (uncut) for comparison (Table 1). The pre-harvest spray was applied in August 2002 with Vision ${ }^{\mathrm{Tw}}$ (active ingredient glyphosate) at $1.05 \mathrm{~kg} \mathrm{ha}^{-1}$ (in $20 \mathrm{~L}$ carrier volume) prior to clearcutting, which occurred fall 2002 to early winter 2003. Harvesting was followed (as appropriate for treatments) by mechanical site preparation (cater- 
Table 1. Descriptions of study treatments

\begin{tabular}{|c|c|c|c|c|}
\hline Treatment & $\begin{array}{l}\text { Harvesting } \\
\text { method }\end{array}$ & $\begin{array}{l}\text { Site } \\
\text { preparation }\end{array}$ & $\begin{array}{l}\text { Planting } \\
\left(\text { stems ha } \text { ha }^{-1}\right)\end{array}$ & Chemical tending with glyphosate \\
\hline Pre-harvest spray & Clearcut & Yes & 1500 & Aerial spray at $1.05 \mathrm{~kg}$ a.e. $\mathrm{ha}^{-1} 3-4$ months before harvest \\
\hline $\begin{array}{l}\text { Partial spray }{ }^{\mathrm{a}} \\
\quad \text { Sprayed corridors } \\
\text { Unsprayed corridors }\end{array}$ & $\begin{array}{l}\text { Clearcut } \\
\text { Clearcut }\end{array}$ & $\begin{array}{l}\text { Yes } \\
\text { None }\end{array}$ & $\begin{array}{l}1500 \\
\text { None }\end{array}$ & $\begin{array}{l}\text { Ground spray at } 1.40 \mathrm{~kg} \text { a.e. } \mathrm{ha}^{-1} 2 \text { years post-planting } \\
\text { None }\end{array}$ \\
\hline $\begin{array}{l}\text { Partial cut } \\
\text { Harvested corridors } \\
\text { Leave corridors }\end{array}$ & $\begin{array}{l}\text { Clearcut } \\
\text { None }\end{array}$ & $\begin{array}{l}\text { Yes } \\
\text { None }\end{array}$ & $\begin{array}{l}1500 \\
\text { None }\end{array}$ & $\begin{array}{l}\text { None } \\
\text { None }\end{array}$ \\
\hline Broadcast spray & Clearcut & Yes & 1800 & Aerial spray at $1.40 \mathrm{~kg}$ a.e. $\mathrm{ha}^{-1} 2$ years post-planting \\
\hline Uncut & None & None & None & None \\
\hline
\end{tabular}

aLogging machine travelled in the sprayed corridors that were allocated for conifer regeneration.

pillar D-8 tractor with angle blade) in September 2003 and planting of one-year-old container jack pine at 1500 to 1800 seedlings ha ${ }^{-1}$ in May to June 2004. Post-harvest spray was applied in August 2005 with Vision ${ }^{\mathrm{Th}}$ at $1.40 \mathrm{~kg}$ acid equivalent (a.e.) $\mathrm{ha}^{-1}$ (in $20 \mathrm{~L}$ carrier volume). Compared to the uncut reference stands $\left(25.44 \mathrm{~m}^{2} \mathrm{ha}^{-1}\right)$, partial cutting removed $43 \%$ of the overstory basal area, followed by an additional $10 \%$ loss to windthrow by year 5 post-harvest (Man et al. 2011).

Each of the treatment areas ranged from 16 to 20 ha with 24 sampling clusters established systematically in a nominal $60 \mathrm{~m} \times 60 \mathrm{~m}$ grid, with a minimum 40-m-wide treatment buffer (MacDonald et al. 2003). The cluster spacing in the partial spray and partial cut treatments was varied to ensure that the 24 regeneration clusters were evenly distributed between strips or corridors.

\section{Sampling}

Each sampling cluster was $2.26 \mathrm{~m}$ in radius and consisted of four $4-\mathrm{m}^{2}$ plots (quadrants) for assessing growth of planted jack pine and natural regeneration, following standard regeneration survey methods for Ontario (Chaudry 1981).

Percent vegetation cover by shrubs, herbaceous species, ferns, grasses, and mosses in two plots and light levels at two heights ( $0.5 \mathrm{~m}$ and $4.0 \mathrm{~m}$ above ground) were recorded at six selected regeneration clusters systematically located within treatment areas and evenly distributed between treatment corridors in partial spray and partial cut. Digital images were taken with a Nikon D 90 camera and a Sigma $4.5 \mathrm{~mm}$ f/2.8 EX DC HSM circular fisheye lens to calculate total light transmittance with Gap Light Analyzer (Frazer et al. 1997).

Natural regeneration was surveyed at year 10 post-treatment in all four plots of each cluster. All live trees were identified by species and measured for total height.

The growth of planted jack pine was assessed on the five seedlings closest to the cluster centre. The total height of each sampled seedling was measured retrospectively for five years (years 1 to 5) at year 5 and two years (years 9 and 10) at year 10 post-planting. Other measurements at year 10 included total height, root collar diameter, stem diameter at breast height, basal diameter and length of the dominant branch (longest of entire crown), height of the dominant branch, and height to live crown (first live branch).

\section{Data analyses}

Analysis of variance was used to assess differences among treatments for (1) percent vegetation cover and total light transmittance; (2) total density and height of natural regeneration by species group (broadleaves and conifers); and (3) total height, height increment at year 10, root collar diameter, diameter at breast height, levels of natural pruning (branch length and diameter, height of dominant branch, height to live crown, and live crown ratio), stem taper (diameter to height ratio), and mortality (between years 5 and 10) of planted jack pine at year 10 post-planting. Data were analyzed based on a randomized complete block design with three replications. Covariance structure $\mathrm{SP}(\mathrm{POW})$ was used for repeated measurements of seedling height after planting due to unequally spaced time intervals (Littell et al. 1996). Data collected at the cluster level were averaged to the treatment level prior to statistical analysis with Proc Mixed (SAS 9.3, SAS Institute Inc. 2010). Since mortality is a proportion, Proc GLIMMIX was used. Data for repeated height measurements were transformed to achieve normality based on a visual assessment and Shapiro-Wilk's test of residuals. When treatment effects were significant $(p<0.05)$, multiple comparisons of treatment means were performed along with $P$-value correction using Tukey's method in SAS 9.3 (SAS Institute Inc. 2010) or Bonferroni's method (repeated height measurements only).

\section{Results}

\section{Vegetation cover and light transmittance}

Except for herbs $(p=0.036)$, significant differences in vegetation cover were not detected among treatments despite apparent trends of high shrub and herb cover in the pre-harvest spray, fern cover in the partial spray, grass cover in the broadcast spray, and moss cover in the uncut reference stand (Fig. 1).

Total light transmittance was highest in the broadcast spray treatment and lowest in the uncut reference stand, although the difference at $0.5 \mathrm{~m}$ above ground was not significant ( $p=0.062$ at $0.5 \mathrm{~m}$ and $p<0.001$ at $4.0 \mathrm{~m}$ for overall treatment effect) (Fig. 2). Light transmittance in the partial cut treatment did not differ from that in the pre-harvest spray or partial spray treatments at $0.5 \mathrm{~m}$ but was significantly lower at $4.0 \mathrm{~m}$. In the partial spray and partial cut treatments, light transmittance was higher in sprayed than 


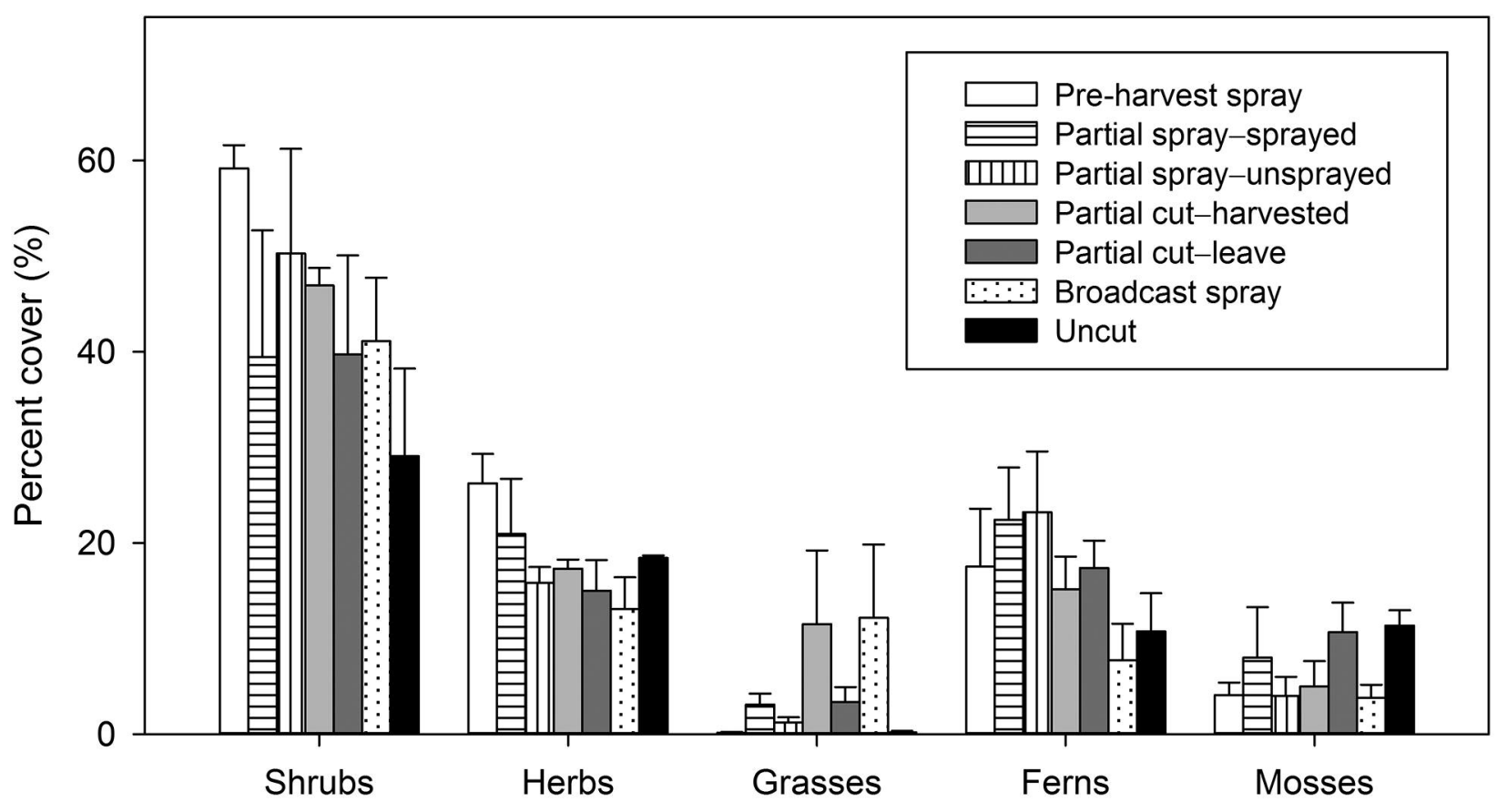

Fig 1. Percent vegetation cover (means \pm SE) at year 10 post-treatment. Means are provided for sprayed and unsprayed corridors in the partial spray treatment and for harvested and unharvested (leave) corridors in the partial cut treatment. Significant differences $(p<0.05)$ among treatments were only evident for herbaceous species (herbs).

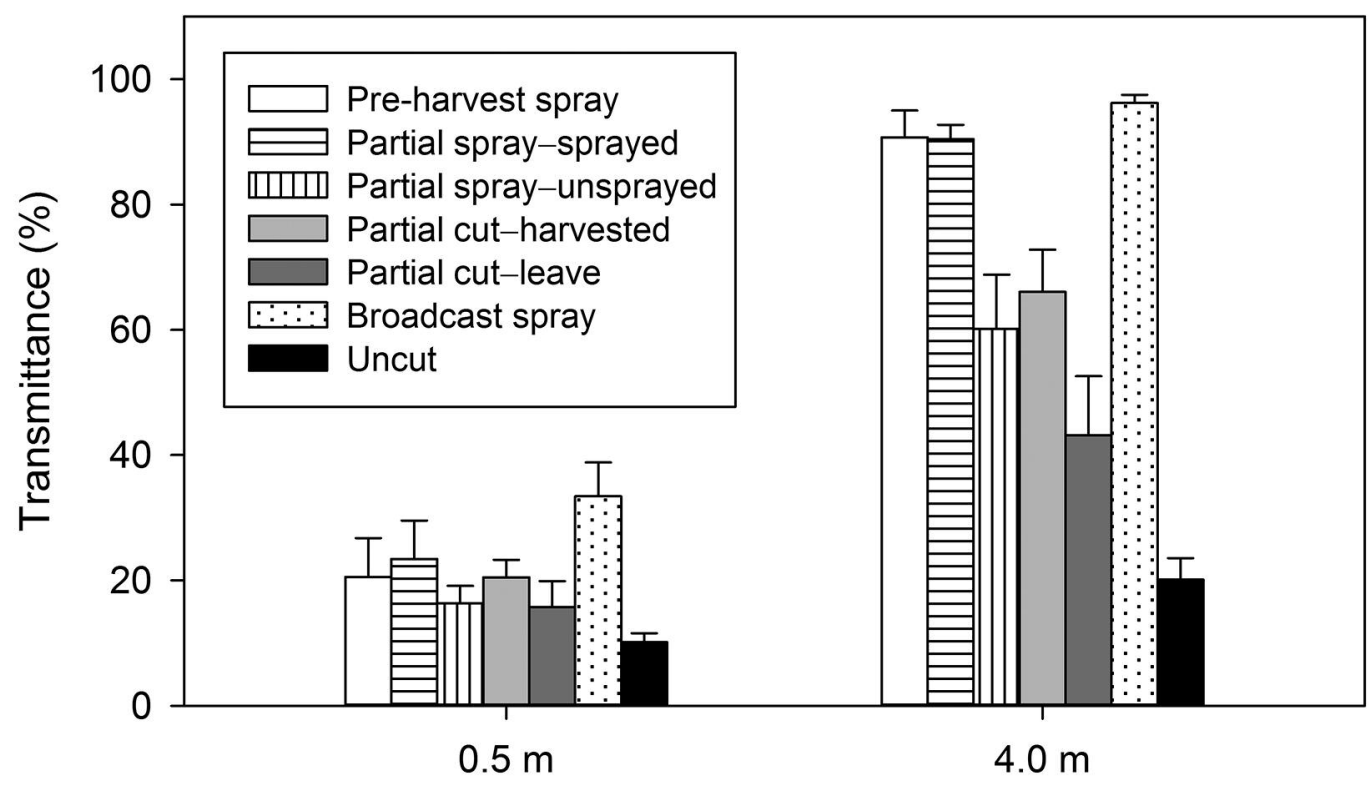

Fig. 2. Total light transmittance (means \pm SE) at year 10 post-treatment. Means are provided for sprayed and unsprayed corridors in the partial spray treatment and for harvested and unharvested (leave) corridors in the partial cut treatment. No significant $(p<0.05)$ treatment effects were detected. 

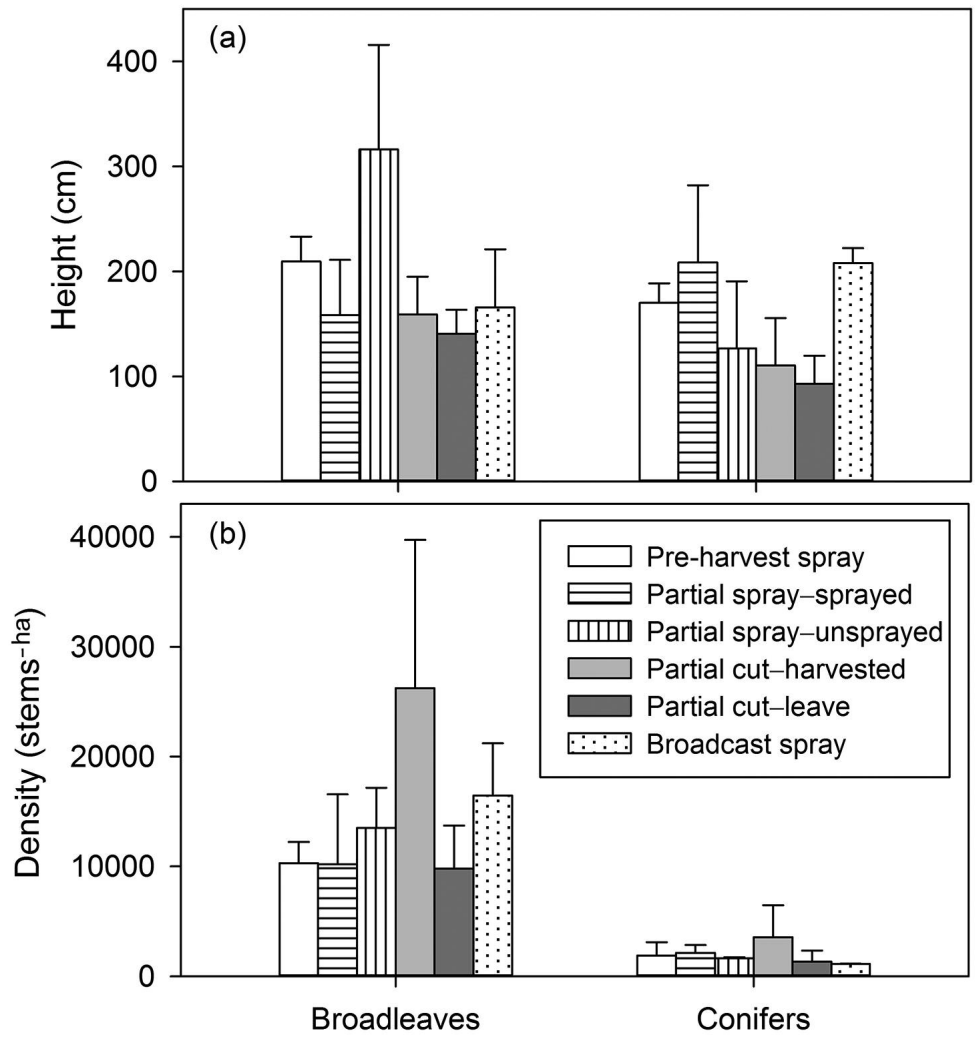

Fig. 3. Height (a) and density (b) of natural regeneration (means \pm SE) at year 10 posttreatment. Means are provided for sprayed and unsprayed corridors in the partial spray treatment and for harvested and unharvested (leave) corridors in the partial cut treatment. No significant $(p<0.05)$ treatment effects were detected.

unsprayed corridors and in harvested than unharvested corridors at both $0.5 \mathrm{~m}$ and $4.0 \mathrm{~m}$ above ground, with the differences greater at $4.0 \mathrm{~m}$.

\section{Natural regeneration}

Significant differences among treatments were not detected for height and total density of broadleaf regeneration, despite apparently taller trees in the unsprayed corridors of the partial spray treatment (over $3.0 \mathrm{~m}$ ) and higher density in the harvested corridors in the partial cut treatment (over 25000 stems ha $^{-1}$ ) (Fig. 3). Red maple was the most abundant broadleaf species in all treatments, and particularly prevalent in the partial cut (Table 2). The density of aspen suckers was about 6000 stems ha $^{-1}$ in the unsprayed corridors of the partial spray treatment, twice that in the other treatments. The average height of aspen suckers was $3.14 \mathrm{~m}$ in the pre-harvest spray treatment, $2.39 \mathrm{~m}$ and $4.50 \mathrm{~m}$ in the sprayed and unsprayed corridors of the partial spray treatment, $3.14 \mathrm{~m}$ and $3.96 \mathrm{~m}$ in the harvested and leave corridors of the partial cut treatment, and $2.72 \mathrm{~m}$ in the broadcast spray treatment.

Similarly, significant differences among treatments were not detected for height and density of natural conifer regeneration (Fig. 3). Average conifer height was about $2.1 \mathrm{~m}$ in sprayed corridors of the partial and broadcast spray treat- ments, $1.7 \mathrm{~m}$ in the pre-harvest spray treatment, and less than $1.5 \mathrm{~m}$ in the other treatments/corridors. Total conifer density was about 3500 stems ha $^{-1}$ in the harvested corridors of the partial cut treatment but below 2000 stems ha $^{-1}$ in most other treatments/corridors (Table 2). Among the three dominant conifers, balsam fir was most abundant in the leave corridors of the partial cut treatment (followed by harvested corridors), jack pine in the sprayed corridors of the partial spray treatment (followed by pre-harvest spray and broadcast spray treatment), and black spruce in the harvested corridors of the partial cut treatment (followed by sprayed corridors of the partial spray and pre-harvest spray treatments) (Table 2).

\section{Growth and quality of planted jack pine}

The total height of planted jack pine did not differ significantly among treatments until year 5 (Fig. $4, p<0.001$ for treatment by time interaction). Seedling height in the partial cut increasingly lagged behind that in the herbicide treatments, but did not differ significantly among the three spray treatments 10 years after planting. The average height of planted pine at year 10 ranged from $4.43 \mathrm{~m}$ in the partial spray to $3.37 \mathrm{~m}$ in the partial cut treatment. The average diameter (root collar diameter and diameter at breast height) and year 10 height increment were also lowest in the partial cut, but highest in the broadcast spray treatment (Table 3).

Planted jack pine seedlings generally had better growth and lower mortality in the broadcast spray treatment, but larger branches (length and diameter), shorter branch-free stems (height of dominant branch and height to live crown), higher live crown ratios, and greater stem taper (smaller height-to-diameter ratio) than those in the partial cut treatment (Table 3). Growth and quality attributes of the seedlings did not differ significantly among the three spray treatments despite a consistent pattern of apparently greater growth attributes in the broadcast spray treatment and wood quality attributes in the pre-harvest spray treatment.

\section{Discussion}

Most differences among treatment means for vegetation cover were not statistically significant (Fig. 1). The greater than average shrub and herb cover in the pre-harvest spray treatment may reflect the low post-harvest broadleaf density (Man et al. 2011) and lack of direct herbicide damage, and the greater moss cover in the uncut plot may indicate the absence of harvesting and site preparation damage (Hart and Chen 2006, Man et al. 2010) (Table 1). Grasses, however, became most abundant in the broadcast spray treatment, likely due to increased light transmittance (Fig. 2) associated with the high levels of disturbance and herbicide use.

In contrast to the observations five years after treatment 
Table 2. Density of natural regeneration [stems ha-1 ${ }^{-1}$ by species and treatment/treatment corridor at year 10 post-treatment

\begin{tabular}{|c|c|c|c|c|c|c|c|c|c|c|c|c|}
\hline \multirow[b]{2}{*}{$\begin{array}{l}\text { Treatments/treatment } \\
\text { corridors }\end{array}$} & \multicolumn{4}{|c|}{ Broadleaves } & \multirow[b]{2}{*}{ Total } & \multicolumn{7}{|c|}{ Conifers } \\
\hline & $\begin{array}{c}\text { Black } \\
\text { ash }\end{array}$ & $\begin{array}{c}\text { Trembling } \\
\text { aspen }\end{array}$ & $\begin{array}{l}\text { White } \\
\text { birch }\end{array}$ & $\begin{array}{c}\text { Red } \\
\text { maple }\end{array}$ & & $\begin{array}{l}\text { Balsam } \\
\text { fir }\end{array}$ & $\begin{array}{l}\text { Jack } \\
\text { pine }\end{array}$ & $\begin{array}{l}\text { White } \\
\text { pine }\end{array}$ & $\begin{array}{c}\text { Black } \\
\text { spruce }\end{array}$ & $\begin{array}{l}\text { White } \\
\text { spruce }\end{array}$ & Tamarack & Total \\
\hline Pre-harvest spray & 0 & 3030 & 2300 & 4965 & 10295 & 208 & 790 & 0 & 825 & 61 & 9 & 1893 \\
\hline $\begin{array}{l}\text { Partial spray-sprayed } \\
\text { corridors }\end{array}$ & 0 & 1563 & 1771 & 6875 & 10209 & 69 & 1146 & 17 & 903 & 0 & 0 & 2135 \\
\hline $\begin{array}{l}\text { Partial spray-unsprayed } \\
\text { corridors }\end{array}$ & 0 & 6215 & 451 & 6840 & 13506 & 191 & 399 & 0 & 556 & 503 & 0 & 1649 \\
\hline $\begin{array}{l}\text { Partial cut-harvested } \\
\text { corridors }\end{array}$ & 87 & 2674 & 5191 & 18299 & 26251 & 469 & 295 & 0 & 2517 & 260 & 17 & 3558 \\
\hline Partial cut-leave corridors & 0 & 1389 & 660 & 7760 & 9809 & 1215 & 0 & 0 & 104 & 0 & 17 & 1336 \\
\hline Broadcast spray & 0 & 3151 & 2266 & 11024 & 16441 & 156 & 668 & 0 & 226 & 35 & 26 & 1111 \\
\hline
\end{tabular}

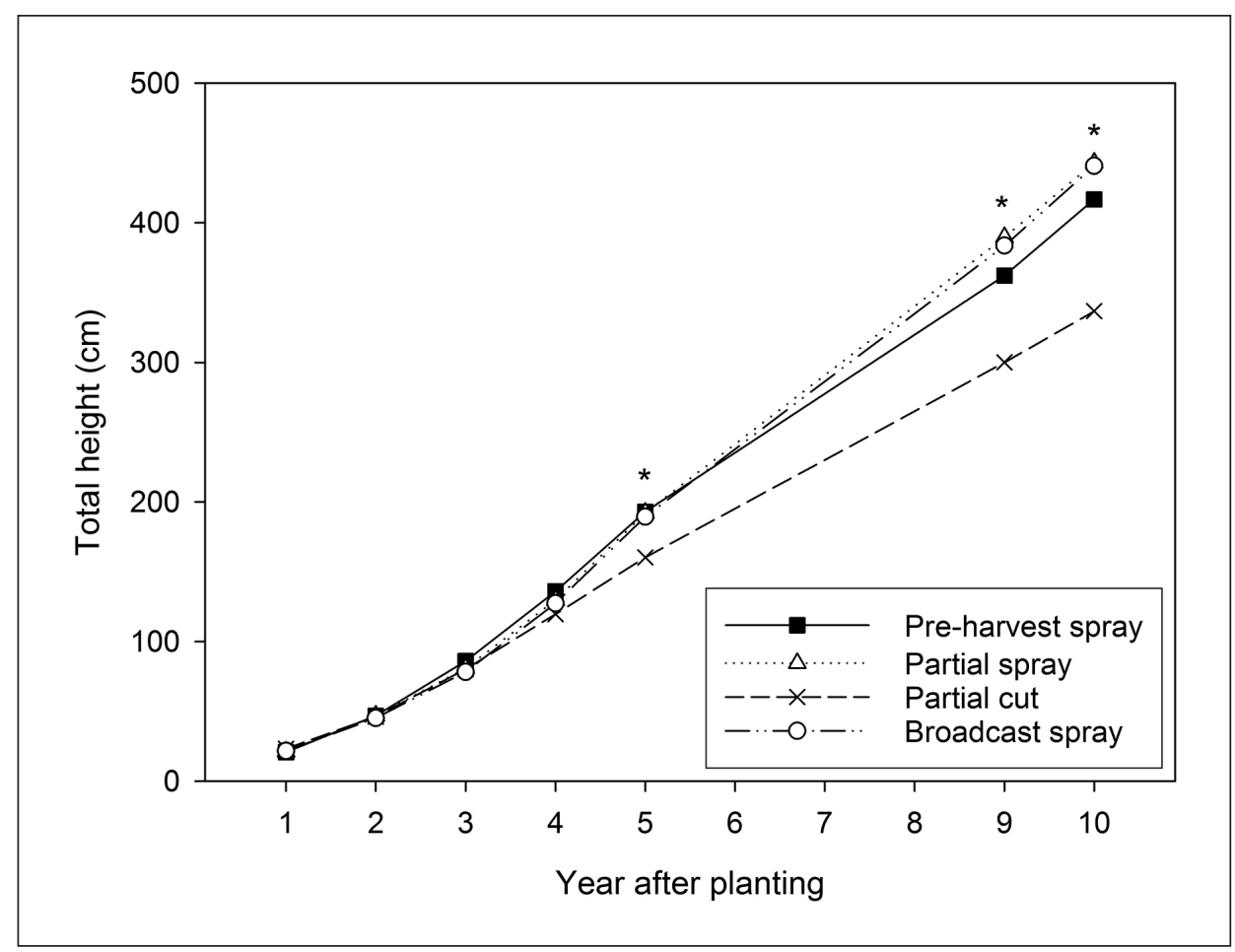

Fig. 4. Total height of jack pine seedlings 10 years after planting by treatment. Significant differences among treatments $(p<0.05)$ are indicated by *.

when differences were apparent (Man et al. 2011), after 10 years light transmittance at $0.5 \mathrm{~m}$ above ground was similar for most treatments (Fig. 2). The exception was the broadcast spray treatment where the statistically non-significant higher transmittance may indicate prolonged effects of post-harvest herbicide spray on vegetation. At year 10 post-treatment, light transmittance at $4.0 \mathrm{~m}$ above ground was close to $100 \%$ in the pre-harvest spray, sprayed corridors of the partial spray, and broadcast spray treatments because the regeneration was generally less than $4.0 \mathrm{~m}$ tall (Fig. 3). In the unsprayed corridors of the partial spray treatment, most aspen suckers exceeded $4.0 \mathrm{~m}$ and in the partial cut treatment, most residual overstory trees remained, reducing light transmittance at $4.0 \mathrm{~m}$ in both the harvested and leave corridors.

Height growth of natural broadleaf regeneration in the pre-harvest spray treatment (Fig. 3) may have benefited from the low density of broadleaf regeneration and lack of herbicide damage. Similar to the findings by Man et al. (2010) in aspen-spruce mixtures on fine-textured soils, the density of aspen suckers in the pre-harvest spray treatment was similar to that in the broadcast spray and harvested corridors of the partial cut treatment, and about half that in the unsprayed corridors in the partial spray treatment (close to typical clearcut). This may have helped natural regeneration of conifers such as jack pine and black spruce (see Table 2 for density and Fig. 3 for height) that require high temperatures to open serotinous cones (Rudolph and Laidly 1990) and light to survive and grow (Bell 1991). The highest natural regeneration density of black spruce was in the harvested corridors of the partial cut treatment where seed from residual trees in the leave corridors likely supplemented that from branches of felled trees. Despite apparently large differences among treatments, the lack of statistically significant differences in height and density of natural regeneration may be attributed to local variations in site and stand conditions over the relatively large treatment areas used in this study.

Growth and mortality of planted jack pine in the pre-harvest spray did not differ significantly from that in the postharvest spray treatments (sprayed corridors in the partial 
Table 3. Seedling size at year 10 and mortality (since year 5) (least square means) by treatment. Means within rows with different letters differ significantly $(p<0.05)$, based on multiple comparisons of means and P-value correction using Tukey's method

\begin{tabular}{|c|c|c|c|c|}
\hline \multirow[b]{2}{*}{$\begin{array}{l}\text { Measured } \\
\text { attribute }\end{array}$} & \multicolumn{4}{|c|}{ Treatment } \\
\hline & $\begin{array}{c}\text { Pre- } \\
\text { harvest } \\
\text { spray }\end{array}$ & $\begin{array}{l}\text { Partial } \\
\text { spray }\end{array}$ & $\begin{array}{c}\text { Partial } \\
\text { cut }\end{array}$ & $\begin{array}{c}\text { Broadcast } \\
\text { spray }\end{array}$ \\
\hline $\begin{array}{l}\text { Year } 10 \text { total height }(\mathrm{m}) \\
(p=0.002)\end{array}$ & $4.17 \mathrm{ab}$ & $4.43 \mathrm{a}$ & $3.37 \mathrm{~b}$ & $4.41 \mathrm{a}$ \\
\hline $\begin{array}{l}\text { Year } 10 \text { height } \\
\text { increment }(\mathrm{m}) \\
(p=0.032)\end{array}$ & $0.55 \mathrm{ab}$ & $0.55 \mathrm{ab}$ & $0.44 \mathrm{~b}$ & $0.59 \mathrm{a}$ \\
\hline $\begin{array}{l}\text { Diameter at breast } \\
\text { height }(\mathrm{cm})(p<0.001)\end{array}$ & $5.43 a$ & $6.02 \mathrm{a}$ & $2.89 \mathrm{~b}$ & $6.43 a$ \\
\hline $\begin{array}{l}\text { Root collar diameter } \\
(\mathrm{cm})(p<0.001)\end{array}$ & $7.06 a$ & $7.75 a$ & $4.01 \mathrm{~b}$ & $8.58 \mathrm{a}$ \\
\hline $\begin{array}{l}\text { Height/diameter ratio } \\
(p<0.001)\end{array}$ & $0.84 b$ & $0.77 b$ & $1.31 \mathrm{a}$ & $0.72 b$ \\
\hline $\begin{array}{l}\text { Basal diameter of } \\
\text { dominant branch } \\
(\mathrm{cm})(p<0.001)\end{array}$ & $1.84 \mathrm{a}$ & $2.05 a$ & $0.90 \mathrm{~b}$ & $2.29 \mathrm{a}$ \\
\hline $\begin{array}{l}\text { Length of dominant } \\
\text { branch }(\mathrm{m})(p<0.001)\end{array}$ & $1.48 \mathrm{a}$ & $1.61 \mathrm{a}$ & $0.80 \mathrm{~b}$ & $1.75 \mathrm{a}$ \\
\hline $\begin{array}{l}\text { Height of dominant } \\
\text { branch }(\mathrm{m})(p=0.801)\end{array}$ & $1.58 \mathrm{a}$ & $1.57 \mathrm{a}$ & $1.58 \mathrm{a}$ & $1.52 \mathrm{a}$ \\
\hline $\begin{array}{l}\text { Height to live crown (m) } \\
(p=0.287)\end{array}$ & $1.02 \mathrm{a}$ & $0.94 \mathrm{a}$ & $1.07 \mathrm{a}$ & $0.81 \mathrm{a}$ \\
\hline $\begin{array}{l}\text { Live crown ratio }(\%) \\
(p=0.006)\end{array}$ & $75 \mathrm{ab}$ & $78 \mathrm{ab}$ & $64 b$ & $81 \mathrm{a}$ \\
\hline $\begin{array}{l}\text { Mortality (\%) } \\
(p=0.003)\end{array}$ & $6.3 \mathrm{~b}$ & $3.2 \mathrm{~b}$ & $21.3 \mathrm{a}$ & $4.1 \mathrm{~b}$ \\
\hline
\end{tabular}

spray and broadcast spray treatments) at year 10 post-planting (Table 3). The inferior height growth of jack pine seedlings in harvested corridors of the partial cut treatment after year 5 (Fig. 4) may be explained by the increasing demand for light as seedlings grew (Givnish 1988, Lieffers et al. 1999, Messier et al. 1999). This effect occurred slightly earlier than with spruce (Man et al. 2013), presumably due to jack pine's lower shade tolerance (Bakuzis and Hansen 1959) and the vigorous growth of broadleaves such as red maple, which added to the shade cast by residual overstory trees (Man et al. 2010).

In the pre- and post-harvest spray treatments, given the high light availability at $4.0 \mathrm{~m}$ (Fig. 2) and that the majority of pines were above the shrub layer and generally taller than broadleaf regeneration in the mixtures, planted jack pine are expected to dominate in the mixedwood stands with broadleaves. In the harvested corridors of the partial cut treatment, some seedlings were suppressed and displayed low vigour 10 years after planting, but most were as tall as competing shrubs and broadleaf regeneration. Reduced growth and high mortality of jack pine in the harvested corridors of the partial cut treatment were offset by better wood quality-related attributes, including smaller branch (and therefore knot) sizes, longer branch-free stem sections, and less stem taper (Willcocks and Bell 1994) that may be particularly important to jack pine (Rudolph and Laidly 1990, Lu et al. 2012).

Among the treatments compared in this study, pre-harvest spray produced a good balance between growth (height and diameter) and quality (branch size, branch-free stem length, and stem taper), broadcast spray maximized growth rate, and partial cutting produced the best overall tree quality but also had the highest mortality rate. Although broadleaf density in the broadcast spray treatment was nearly 6000 stems ha $\mathrm{ha}^{-1}$ higher than that in the pre-harvest spray (10 000 stems ha $^{-1}$ ), the trees were noticeably smaller due to post-harvest herbicide damage and were not as effective as broadleaves in the pre-harvest spray in influencing wood quality-related attributes of jack pine. The superior height of broadleaf regeneration in the unsprayed corridors of the partial spray treatment also provided shade to help natural pruning of jack pine relative to the broadcast spray treatment (Table 3; Fig. 3). However, the partial spray treatment was more expensive and resulted in only $50 \%$ of the area allocated to conifer production (Man et al. 2010). As in aspen-spruce mixtures (Man et al. 2013), pre-harvest spray could eliminate the need for resorting to high planting density to maintain jack pine quality and subsequent stand density management to achieve adequate growth, ultimately reducing management costs. In the pre-harvest spray, the relatively low mortality and good growth of jack pine and weak aspen regeneration indicate that glyphosate concentration could be adjusted to favour jack pine wood quality or improve aspen regeneration.

The results of this study demonstrate that pre-harvest spray is a promising technique for managing mixtures of shade-intolerant aspen and jack pine, as was shown for shadeintolerant-tolerant mixtures of aspen and spruce (Man et al. 2010, 2013). Spraying mature trembling aspen with glyphosate prior to harvest was as effective as partial cutting and post-harvest broadcast spray treatments in suppressing trembling aspen regeneration density. Furthermore, in the pre-harvest spray treatment the growth of planted jack pine was similar and the quality was superior to that in the partial spray and broadcast spray treatments 10 years after planting. As found for aspen-spruce mixtures on fine-textured soil (Man et al. 2010, 2013), pre-harvest spray is an effective silvicultural technique for producing intimate mixtures of healthy and productive trembling aspen and conifers.

\section{Acknowledgements}

We thank J. Rice, D. Niblett, S. Stuart, J. Schnare, M. Beaudoin, S. Fleming, M. Roberts, C. Andrews, and G. Fuss of the Ontario Ministry of Natural Resources and Forestry (OMNRF) for their involvement in study establishment and data collection. We also thank the project partners: Domtar Inc. (Timmins) and Forest Engineering Research Institute of Canada (FERIC) for their input and support during development and implementation of the study. Two anonymous reviewers and Lisa Buse (OMNRF) provided constructive suggestions on earlier drafts of the paper. Funding was provided by the Ontario Living Legacy Trust, the Ontario Forestry Futures Trust, and OMNRF. 


\section{References}

Bakuzis, E.V. and H.L. Hansen. 1959. A provisional assessment of species synecological requirement in Minnesota forests. University of Minnesota, St. Paul, MN. Mn. For. Notes No. 84.

Béland, M., Y. Bergeron and R. Zarnovican. 1999. Natural regeneration of jack pine following harvesting and site preparation in the Clay Belt of northwestern Quebec. For. Chron. 75: 821-831.

Bell, F.W. 1991. Critical silvics of conifer crop species and selected competitive vegetation in northwestern Ontario. For. Can., Ont. Region, Sault Ste. Marie, Ont., Northwest Ont. For. Tech. Div. Unit, Ministry of Natural Resources, Thunder Bay, Ont. COFDRA Rep. 3310/NWOFTDU Tech. Rep. 19.

Bell, F.W., J. Dacosta, M. Penner, A. Morneault, A. Stinson, B. Towill, N. Luckai and J. Winters. 2011. Longer-term volume tradeoffs in spruce and jack pine plantations following various conifer release treatments. For. Chron. 87: 235-250.

Bell, F.W., M.T. Ter-Mikaelian and R.G. Wagner. 2000. Relative competitiveness of nine early-successional boreal forest species associated with planted jack pine and black spruce seedlings. Can. J. For. Res. 30: 790-800.

Chaudry, M.A. 1981. Regeneration survey manual for Ontario. Ontario Ministry of Natural Resources, Toronto, Ont. 76 p.

Comeau, P.G., R. Kabzems, J. McClarnon and J.L. Heineman. 2005. Implications of selected approaches for regenerating and managing western boreal mixedwoods. For. Chron. 81: 559-574.

Frazer, G.W., J.A. Trofymow and K.P. Lertzman. 1997. A method for estimating canopy cover, vegetation area index, and photosynthetically active photon flux density using hemispherical photography and computerized image analysis techniques. Can. For. Serv., For. Ecosyst. Proc. Network, Pac. For. Cent., Inf. Rep. BC-X-373.

Galloway, R. 1986. Jack pine working group. Silvicultural Guide Series. OMNR Resource Group. Toronto, ON.

Givnish, T.J. 1988. Adaptation to sun and shade: a whole-plant perspective. Aust. J. Plant Physiol. 15: 63-92.

Hart, S.A. and H.Y.H. Chen. 2006. Understory vegetation dynamics of North American boreal forests. Crit. Rev. Plant Sci. 25: 381-397.

Lieffers, V.J., G.W. Armstrong, K.J. Stadt and E.H. Marenholtz. 2008. Forest regeneration standards: are they limiting management options for Alberta's boreal mixedwoods? For. Chron. 84: 76-82.

Lieffers, V.J., C. Messier, K.J. Stadt, F. Gendron and P.G. Comeau. 1999. Predicting and managing light in the understory of boreal forests. Can. J. For. Res. 29: 796-811.

Littell, R.C., G.A. Milliken, W.W. Stroup and R.D. Wolfinger. 1996. SAS system for mixed models. SAS Institute Inc., Cary, NC.

Lu, P., W. Bell, P. Charrette and M. Thompson. 2012. Performance of jack pine (Pinus banksiana) rooted cuttings from proliferated dwarf shoots versus seedlings 8 years after planting. Can. J. For. Res. 42: 1404-1409.

MacDonald, G.B. 1995. The case for boreal mixedwood management: an Ontario perspective. For. Chron. 71: 725-734.
MacDonald, G.B., M.L. Cherry and D.J. Thompson. 2004. Effect of harvest intensity on development of natural regeneration and shrubs in an Ontario boreal mixedwood stand. For. Ecol. Manage. 189: 207-222.

MacDonald, G.B., J.A. Rice, J. McLaughlin, J. Pearce, L. Venier, K. Nystrom and P. Meek. 2003. Developing sustainable mixedwood practices in a stand-level adaptive management (SLAM) framework: project establishment. Ontario Ministry of Natural Resources, Ontario Forest Research Institute, Sault Ste. Marie, ON. For. Res. Inf. Pap. 157.

Man, R. and V.J. Lieffers. 1999. Are mixtures of aspen and white spruce more productive than single species stands? For. Chron. 75: 505-513.

Man, R., J.A. Rice and G.B. MacDonald. 2009. Long-term response of planted conifers, natural regeneration, and vegetation to harvesting, scalping, and weeding on a boreal mixedwood site. For. Ecol. Manage. 258: 1225-1234.

Man, R., J.A. Rice and G.B. MacDonald. 2010. Five-year light, vegetation, and regeneration dynamics of boreal mixedwoods following silvicultural treatments to establish productive aspen-spruce mixtures in northeastern Ontario. Can. J. For. Res. 40: 1529-1541.

Man, R., J.A. Rice and G.B. MacDonald. 2011. Early effects of preand post-harvest herbicide application and partial cutting in regenerating aspen-jack pine mixtures in northeastern Ontario. Can. J. For. Res. 41: 1082-1090.

Man, R., J.A. Rice and G.B. MacDonald. 2013. Performance of planted spruce and natural regeneration after pre- and post-harvest spraying with glyphosate and partial cutting on an Ontario (Canada) boreal mixedwood site. Forestry 86: 475-480.

Messier, C., R. Doucet, J.-C. Ruel, Y. Claveau, C. Kelly and M.J. Lechowicz. 1999. Functional ecology of advance regeneration in relation to light in boreal forests. Can. J. For. Res. 29: 812-823.

Pitt, D.G., A.E. Morneault, P. Bunce and F.W. Bell. 2000. Five years of vegetation succession following vegetation management treatments in a jack pine ecosystem. North. J. Appl. For. 17: 100-109.

Rudolph, T.D. and P.R. Laidly. 1990. Pinus banksiana Lamb. - Jack pine. In R.M. Burns and B.H. Honkala. (eds.). Silvics of North America. Vol. 1. Conifers. pp. 280-293. USDA For. Serv., Washington, DC, Agric. Handbk. 654.

SAS Institute Inc. 2010. Statistical Analysis Software, Version 9.3. SAS Institute Inc., Cary, NC.

Towill, W.D., R.O. Wiltshire and J.C. Desharnais. 2004. Distribution, extent, and importance of boreal mixedwood forests in Ontario. Ontario Ministry of Natural Resources, Peterborough, Ont. Boreal Mixedwood Note 4.

Willcocks, A.J. and F.W. Bell. 1994. Effect of stand density on the growth and timing of harvest and establishment costs of coniferous stands. Ontario Ministry of Natural Resources, Northeast Sci. Technol., South Porcupine, Ont. NEST TN-007. 